\title{
Southward Subsurface Flow Below the Somali Current
}

\author{
Detlef R. Quadfasel \\ Institut für Meereskunde, Universität Hamburg, 2000 Hamburg 13, Federal Republic of Germany
}

FRIEDRICH SCHOTT

Rosenstiel School of Marine and Atmospheric Science, University of Miami, Miami, Florida 33149

\begin{abstract}
The existence of a southward-flowing current beneath the northern part of the seasonally reversing Somali Current is documented in a $2 \frac{1}{2}$-year-long time series of currents obtained at moored stations near $5^{\circ} \mathrm{N}$ about $30 \mathrm{~km}$ off the Somali coast. Its mean annual transport in the layer $150-600 \mathrm{~m}$ amounts to about $5 \times 10^{6} \mathrm{~m}^{3} / \mathrm{s}$. The undercurrent has a pronounced seasonal cycle in phase with the near surface flow, suggesting a close coupling to the monsoonal wind forcing. With the spin-up of the deepreaching northern Somali gyre after the onset of the southwest monsoon, the undercurrent is temporarily destroyed in the northern Somali Basin during June/July but is re-established in August. The undercurrent does not reach $3^{\circ} \mathrm{N}$ but turns offshore north of that latitude.
\end{abstract}

\section{INTRODUCTION}

During the FGGE Indian Ocean Experiment (INDEX) from March to July 1979, observations with moored instrumentation between $5^{\circ} \mathrm{N}$ and $7^{\circ} 30^{\prime} \mathrm{N}$ [Schott and Quadfasel, $1982]$ and with profiling current meters along sections normal to the coast between $2^{\circ} \mathrm{S}$ and $9.5^{\circ} \mathrm{N}$ [Leetmaa et al., 1982 ] showed the existence of a narrow southward undercurrent off the east African coast between $\sim 4^{\circ} \mathrm{N}$ and the northernmost latitude of observations. Near $9^{\circ} \mathrm{N}$ the undercurrent was observed in the depth range 150-600 $\mathrm{m}$, and the core of the undercurrent was observed to rise on its way south. It was still observed in current profiling sections and moored current measurements at $5^{\circ} \mathrm{N}$ but was no longer apparent in current profiling sections normal to the coast at $3^{\circ} \mathrm{N}$. Unfortunately, there were no direct current measurements between these two latitudes where it must have turned offshore.

In this paper we investigate the vertical structure and seasonal variability of the subsurface flow at the depth level of the undercurrent from moored current measurements collected off Somalia near $5^{\circ} \mathrm{N}$ over a time period of several years and from additional observational evidence.

When trying to understand the seasonal change of the subsurface flow off Somalia, one has to be aware of the quite complicated evolution of the near-surface flow pattern in response to the changes of the monsoon wind system, which causes different physical balances to exist in the boundary current during different parts of the year. As to our present knowledge, the surface flow has distinctive quasi-stationary patterns over the course of a year which are briefly summarized as follows:

1. During the winter monsoon, from November to February, the Somali Current flows southward along the East African coast from Ras Hafun (Figure 1) to south of the equator.

2. In the transition period from March to early April, the wind stress curl off Somalia is negative north of about $5^{\circ} \mathrm{N}$ and positive south of there, causing strong onshore flow at

Copyright 1983 by the American Geophysical Union.

Paper number $3 \mathrm{C} 0433$.

0148-0227/83/003C-0433\$05.00 that latitude. Consequently, the surface flow at the Somali coast splits up into a northward and southward branch at $5^{\circ} \mathrm{N}$.

3. In April, after the first occurrence of onshore and northward winds, a shallow northward cross equatorial current develops, which turns offshore north of the equator. The turn-off latitude migrates northward during this time period. North of $\sim 5^{\circ} \mathrm{N}$ the northward current continues.

4. During early May to mid-June, the latitude of offshore turning remains stable at about $3^{\circ}-4^{\circ} \mathrm{N}$ with a strong upwelling wedge at the coast north of the offshore flow. During this time period, a classical upwelling regime exists north of $5^{\circ} \mathrm{N}$ with winds in the $5-10 \mathrm{~m} / \mathrm{s}$ range about parallel to the coast.

5. After the final southwest monsoon onset causing strong winds off northern Somalia with maximum speeds of $20 \mathrm{~m} / \mathrm{s}$ and a very strong anticyclonic curl offshore, a deepreaching northern gyre develops in late June causing strong along-shore flow north of about $7^{\circ} \mathrm{N}$, which turns offshore at $9^{\circ}-10^{\circ} \mathrm{N}$ and in turn generates a second cold upwelling wedge off Ras Hafun. This situation, with the cross-equatorial current turning offshore south of $5^{\circ} \mathrm{N}$, the northern gyre and two upwelling wedges stays about stationary until mid to late August.

6. Then the 'two-wedge' situation collapses. The southern wedge propagates northward, and during late August through September a stationary continuous Somali Current flows parallel to the coast from south of the equator to Ras Hafun where it turns offshore.

The above-described surface flow pattern for the onset and evolution of the summer monsoon is pieced together from the INDEX '79 observations [Leetmaa et al., 1982; Schott and Quadfasel, 1982; Swallow et al., 1983], and satellite SST observations from 1976 to 1979 [Evans and Brown, 1981] and historical data [e.g., Koninklijk Nederlands Meteorologisch Instituut (KNMI), 1952]. The development of the Somali Current system may change considerably in its timing from one year to the next, following the interannual variability of the monsoon wind field, but, the above described sequence seems to be fairly representative, as shown by Swallow and Fieux [1982] from an analysis of historical ship drift observations. There is no conclusive observational evidence as to what happens to the circulation 


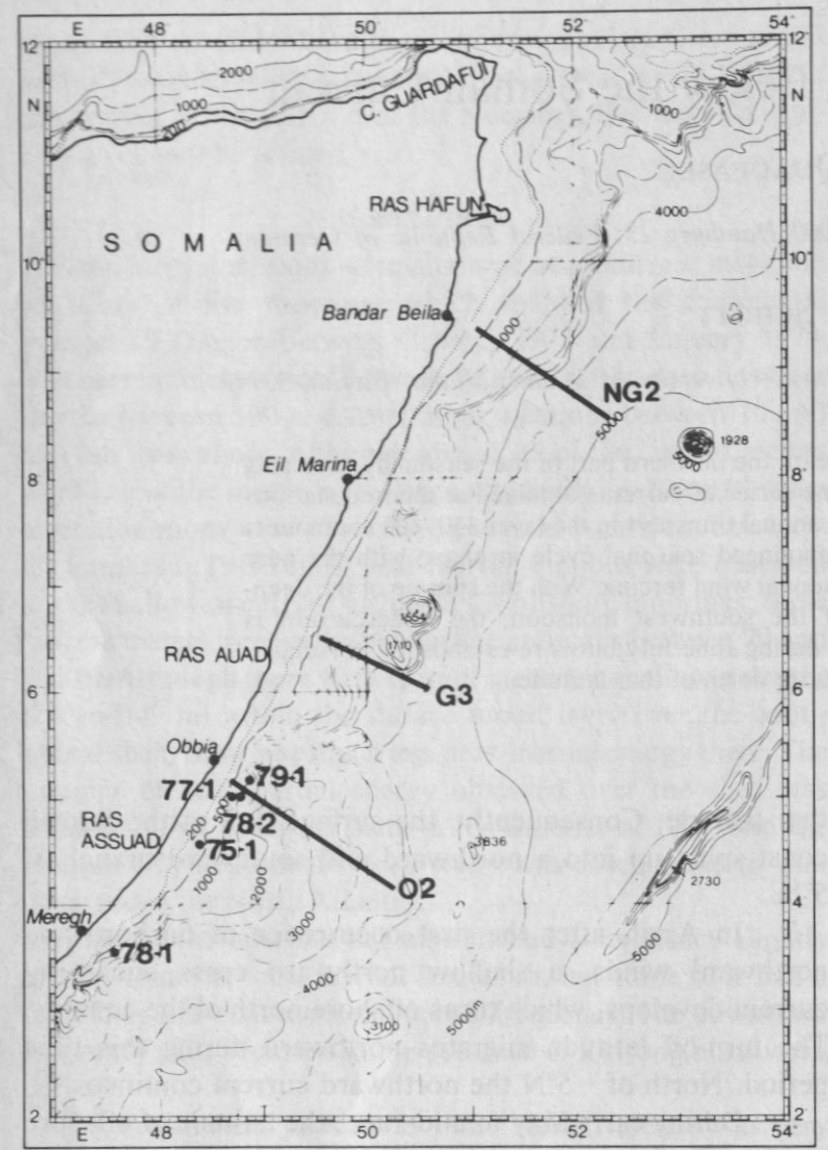

Fig. 1. Location of moorings and sections off the Somali Coast. Heavy dots indicate mooring positions; NG2, G3, and 02 refer to current profiling sections (Figure 5). Depth contours in meters.

pattern after step 6 in the transition period after the summer monsoon and during the onset of the winter monsoon.

During the winter monsoon a southward subsurface flow will obviously be part of the surface circulation, and during various other phases it will be an undercurrent. Following these different physical regimes that govern the surface flow, there will also be different physical balances in the subsurface flow.

\section{OBSERVATIONS}

During four time periods, between August 1975 and July 1979, a subsurface mooring, equipped with Aanderaa RCM-4 current meters, was deployed on the continental slope off Somalia near $5^{\circ} \mathrm{N}$ (Figure 1). In addition, a mooring was located at $3^{\circ} 30^{\prime} \mathrm{N}$ during 1978 , and five more moorings were maintained from March to July 1979 between $5^{\circ} \mathrm{N}$ and $7^{\circ} 30^{\prime} \mathrm{N}$ during FGGE/INDEX. The rotor of one of the instruments for a part-time record at the $130-300 \mathrm{~m}$ level was lost; for that time we introduced an artificial speed of $30 \mathrm{~cm} / \mathrm{s}$ to show at least the directional signal, which was stable during most months. Also, some of the records ended prematurely owing to instrument malfunctions. Some results of the 1975 and the 1979 observations, with respect to the current variability on time scales of weeks to months, have already been presented by Düing [1977] and Schott and Quadfasel [1982]; here, these records will be included for the evaluation of the undercurrent.

The current profile observations reported here stem from measurements with the Aanderaa profiler [Düing and Johnson, 1972] during INDEX '79. The relative current profile measured with this instrument were corrected for ship drifts by ranging on acoustic beacons or by use of satellite navigation to obtain absolute profiles of currents. A conservative estimate of the accuracy of this method is about $\pm 20 \mathrm{~cm} / \mathrm{s}$ [Wilson, 1981].

Monthly averages of the alongshore current speeds (toward $30^{\circ} \mathrm{T}$ ) from the records obtained at the moorings near $5^{\circ} \mathrm{N}$ are plotted in Figure 2 for two depth ranges, $130-300 \mathrm{~m}$ and $430-600 \mathrm{~m}$. The flow is dominantly to the south at both levels, in contrast to the surface flow, which is toward the south only from December to February, during the fully developed NE-monsoon [KNMI, 1952]. At both depth levels a seasonal signal is visible: maximum southward flow of up to $60 \mathrm{~cm} / \mathrm{s}$ is found during the time of the NE-monsoon in December/January, and minimum southward flow, sometimes with current reversals toward north, is observed during the SW-monsoon in June/July.

To illustrate the seasonal signal in more detail, all available data for the two depth ranges (Figure 2) have been averaged to monthly mean values (Figure 3 ). Also plotted are the mean longshore surface currents at $4^{\circ}-6^{\circ} \mathrm{N}$ from historical ship drift data [KNMI, 1952] and the mean longshore component of the wind stress from 1976 to 1979 at this location. The wind stress was derived from synoptic surface wind maps, compiled from standard ship observations for periods of 3 days as described in Schott and FernandezPartagas [1981]. Except for the surface currents where the individual observations are not available, standard error bars are presented on monthly means.

The annual mean flow near $5^{\circ} \mathrm{N}$ at the surface is to the northeast with a speed of $30 \mathrm{~cm} / \mathrm{s}$, while at the two deeper levels it is to the southwest with 17 and $12 \mathrm{~cm} / \mathrm{s}$, respectively (Figure 4). Vertical profiles for different stages of the monsoon cycle are shown in Figure $4 a$. A harmonic analysis of the wind stress time series, of the current time series (Figure 2, where gaps were filled in from Figure 3), and of the mean

ALONGSHORE CURRENT SPEED

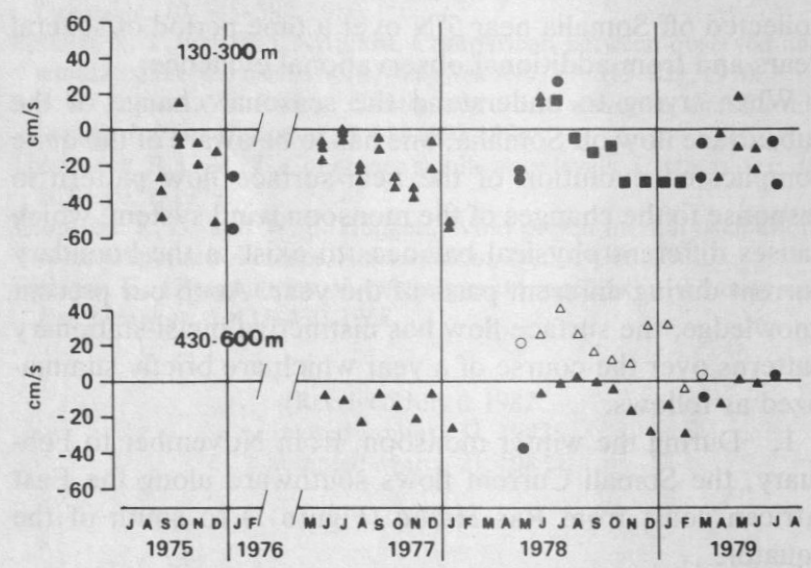

Fig. 2. Monthly alongshore current speeds (positive = northeastward) from moored instruments near $5^{\circ} \mathrm{N}$ for two depth ranges, $130-300 \mathrm{~m}$ and $430-600 \mathrm{~m}$, stations $75-1,77-1,78-2$, and 79-1 (Figure 1). Triangles are monthly means, dots represent means over periods less than 1 month but more than 15 days, and squares denote record where rotor was lost and an artificial speed of $30 \mathrm{~cm} / \mathrm{s}$ has been introduced. Open symbols denote measurements at mooring 78-1, about $200 \mathrm{~km}$ farther to the south. 
annual curve of the surface current shows that the annual signal in all time series is about in phase. The amplitude of the seasonal signal in the currents decreases strongly with depth; from about $60 \mathrm{~cm} / \mathrm{s}$ at the surface to $14 \mathrm{~cm} / \mathrm{s}$ and 9 $\mathrm{cm} / \mathrm{s}$, respectively, in the two subsurface layers (Figure $4 b$ ). In addition to this baroclinic in-phase annual signal, there appears to be a second baroclinic event superimposed during the latter part of the SW-monsoon. While the northward flow at the surface is enhanced by more than $50 \mathrm{~cm} / \mathrm{s}$ during August and September a southward acceleration (i.e. out of phase with the surface flow) is observed at the $130-300 \mathrm{~m}$

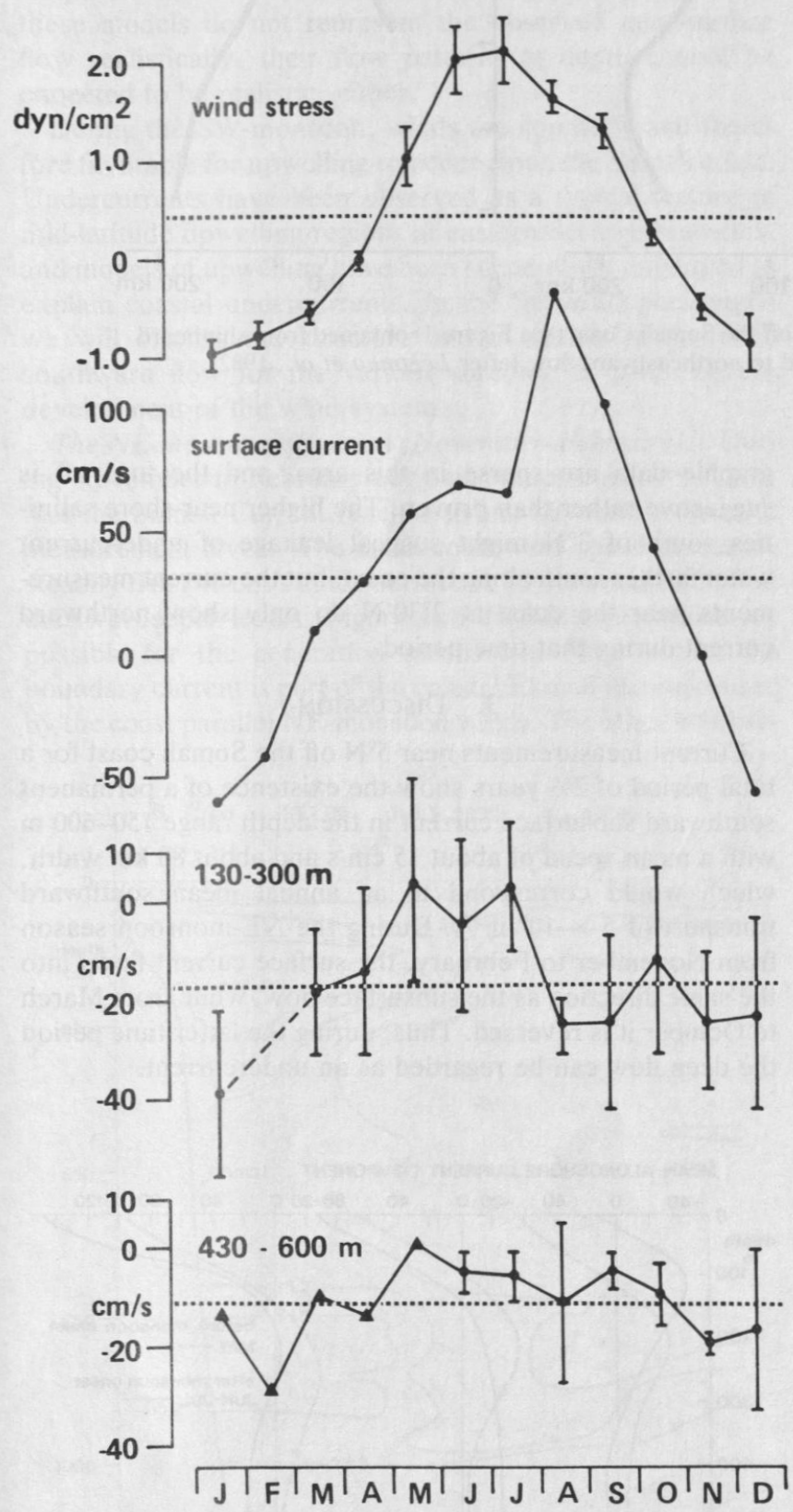

Fig. 3. Overall monthly alongshore components (positive $=$ northeastward) of windstress and currents at various depth levels near $5^{\circ} \mathrm{N}$. Wind data are from 3-day synoptic maps from 1976 to 1979 [Schott and Fernandez-Partagas, 1981] and surface current data are from KNMI [1952]. For the current speeds at the two deep levels all available complete monthly values from 1975 to 1979 (Figure 2) have been used. Standard error bars are indicated. Dotted lines are annual means.

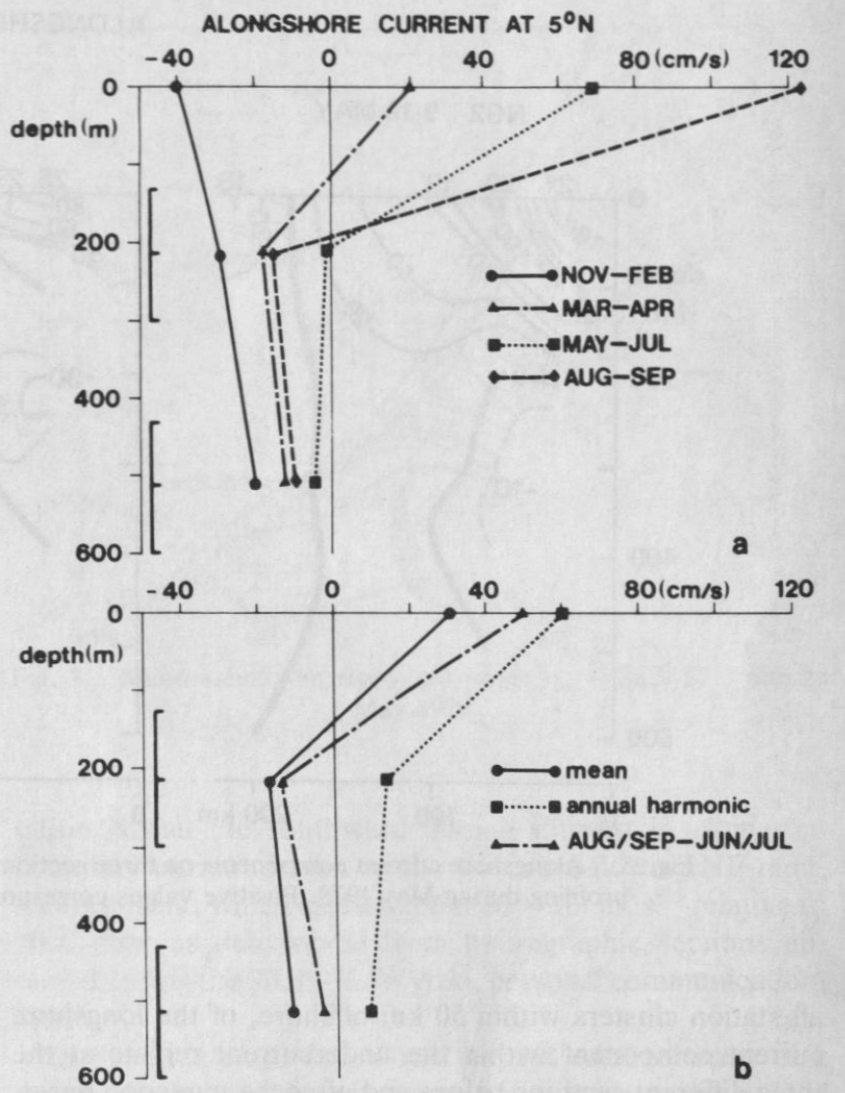

Fig. 4. Mean alongshore current components (positive $=$ northeastward) at surface [KMNI, 1952] and for the two depth intervals indicated by heavy bars at left; $(a)$ means for time periods as indicated; $(b)$ overall means, amplitude of annual harmonic and difference between means of August/September and June/July.

level (Figures $4 a$ and $4 b$ ). This strong acceleration coincides with the break down of the two-gyre circulation, when the southern upwelling wedge present during the early SWmonsoon propagates northward [Evans and Brown, 1981; Swallow et al., 1983], subsequently establishing a continuous boundary current.

The current components normal to the coast at the two depth levels did not show any systematic onshore/offshore flow pattern.

Three quasi-synoptic current profile sections across the boundary flow obtained during May 1979 [Leetmaa et al., 1982] show the spatial structure of the undercurrent between $5^{\circ} \mathrm{N}$ and $9^{\circ} 20^{\prime} \mathrm{N}$ (Figure 5). Maximum speeds in the core of the undercurrent increase from $15 \pm 3 \mathrm{~cm} / \mathrm{s}$ in the north to 60 $\mathrm{cm} / \mathrm{s}$ near $5^{\circ} \mathrm{N}$. Also, the core of the undercurrent rises from about $400 \mathrm{~m}$ to less than $200 \mathrm{~m}$ between these latitudes, while its thickness seems to remain about constant. Measurements farther to the south [Leetmaa et al., 1982], however, show that, at least from April to June 1979, the undercurrent does not reach $3^{\circ} \mathrm{N}$. Thus, it must either surface or turn offshore north of that latitude. This result is confirmed by the moored current observations obtained near $3^{\circ} 30^{\prime} \mathrm{N}$ during 1978 (78-1 in Figure 1, open marks in Figure 2). At $580 \mathrm{~m}$ depth the flow is predominantly toward northeast, in marked contrast to the observations $200 \mathrm{~km}$ farther to the north.

The response of the coastal flow to the final onset of the SW-monsoon during June 1979 is not uniform along the Somali coast. Figure 6 shows mean profiles, averaged over 


\section{ALONGSHORE CURRENT SPEED}
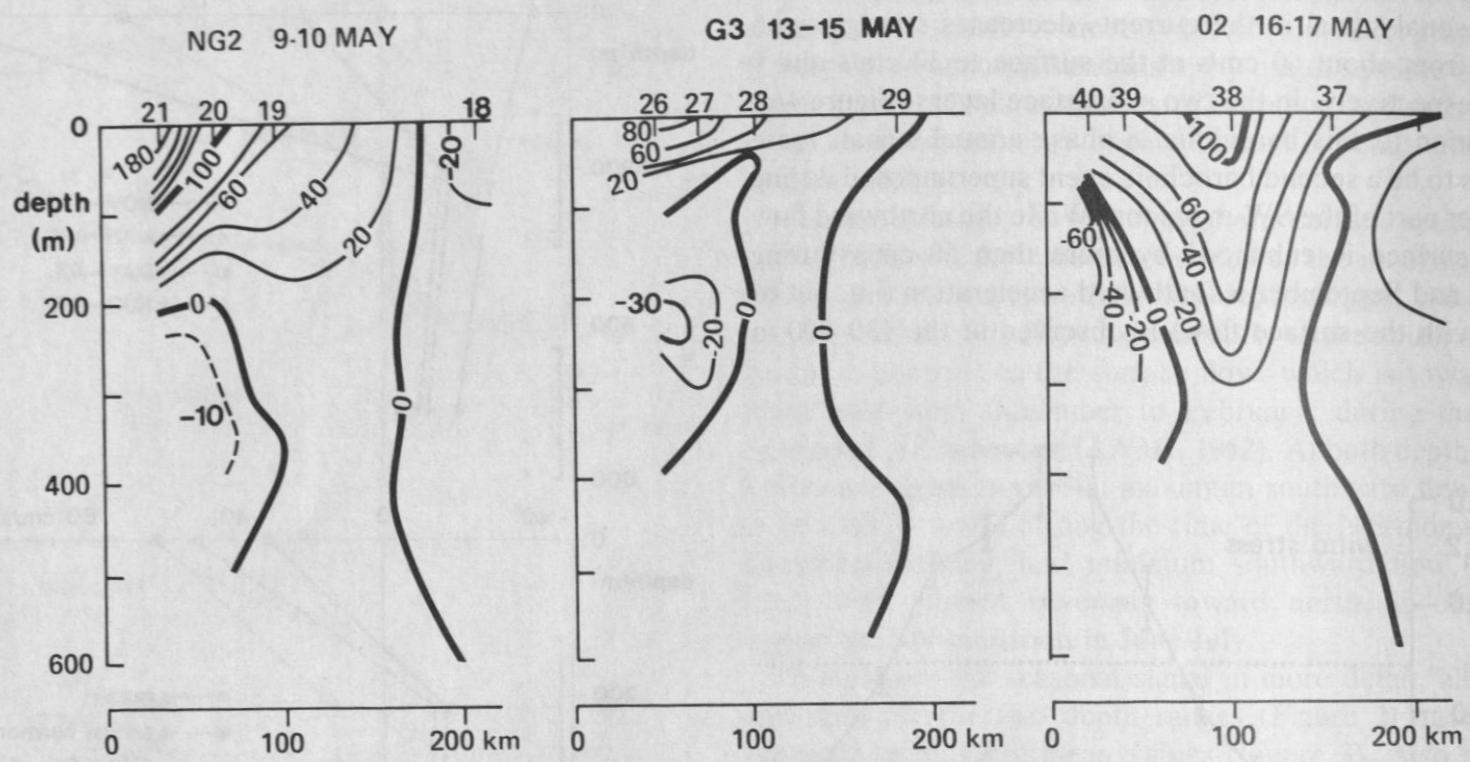

Fig. 5. Alongshore current components on three sections off the Somali Coast (see Figure 1) obtained from shipboard profiling during May 1979. Positive values correspond to northeastward flow [after Leetmaa et al., 1982].

all station clusters within $50 \mathrm{~km}$ offshore, of the longshore current component within the undercurrent regime at the three different sections before and after the monsoon onset. While near $5^{\circ} \mathrm{N}$ the vertical structure of the flow does not change substantially except for an uplifting of the undercurrent core, the profiles in the northern Somali Basin, at $6^{\circ} 30^{\prime} \mathrm{N}$ and $8^{\circ} \mathrm{N}$, do not show the undercurrent anymore. The reason is that the northern Somali gyre spins up in a dominantly barotropic mode shortly after the monsoon onset and subsequently propagates toward the coast [Schott and Quadfasel, 1982]. The onshore flow at the southern flank of this eddy, which reaches to at least $1000 \mathrm{~m}$ depth, splits at the coast north of $7^{\circ} \mathrm{N}$ and superimposes on the existing boundary flow. As a result we find uniformly southward flow below about $200 \mathrm{~m}$ depth at $6^{\circ} 30^{\prime} \mathrm{N}$ but not at $5^{\circ} \mathrm{N}$, which is not affected by the northern gyre, while farther to the north the flow at all depths is toward northeast (Figure 6). Thus, with the spin up of the gyre, the undercurrent is totally destroyed in the northern Somali Basin.

The INDEX ' 79 hydrographic data suggest that the undercurrent south of $6^{\circ} \mathrm{N}$ has higher salinities than the surrounding waters. Figure 7 shows a salinity section across the boundary flow near $5^{\circ} \mathrm{N}$ during July. The shaded area corresponds to the vertical current profile given in Figure 6. The core of the undercurrent is well correlated with the region of high salinities, bounded by a sharp front from the low salinity Subtropical Subsurface water farther offshore. Figure 8 shows the vertically averaged salinity in the isopycnal range $\sigma_{\theta}=26.3-27.0$, which corresponds to a depth range of about $150-450 \mathrm{~m}$. North of about $7^{\circ} \mathrm{N}$ there seems to be a large pool of about constant salinity with no marked gradients along the section running normal to the coast at $9^{\circ} 30^{\prime} \mathrm{N}$.

The high salinity wedge offshore between $3^{\circ}$ and $4^{\circ} \mathrm{N}$ at the undercurrent level (Figure 8) seems to confirm the current profiling results of Leetmaa et al. [1982] (i.e., that the undercurrent turns offshore north of $3^{\circ} \mathrm{N}$ ). However, hydro- graphic data are sparse in this area, and the turn off is suggestive rather than proven. The higher near-shore salinities south of $3^{\circ} \mathrm{N}$ might suggest leakage of undercurrent water farther south along the coast, but the current measurements near the coast at $2^{\circ} 30^{\prime} \mathrm{N}$ do only show northward current during that time period.

\section{Discussion}

Current measurements near $5^{\circ} \mathrm{N}$ off the Somali coast for a total period of $2 \frac{1}{2}$ years show the existence of a permanent southward subsurface current in the depth range 150-600 m with a mean speed of about $15 \mathrm{~cm} / \mathrm{s}$ and about $80 \mathrm{~km}$ width, which would correspond to an annual mean southward transport of $5 \times 10^{6} \mathrm{~m}^{3} / \mathrm{s}$. During the NE-monsoon season from November to February, the surface current flows into the same direction as the subsurface flow, while from March to October it is reversed. Thus, during the latter time period the deep flow can be regarded as an undercurrent.

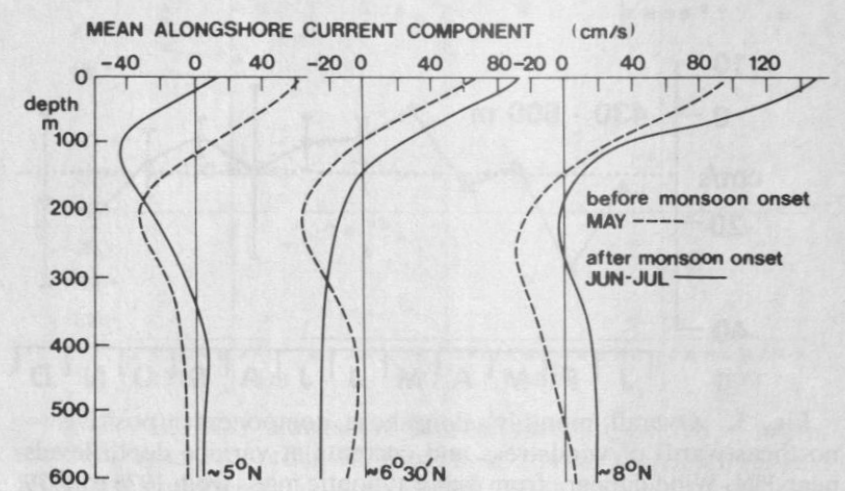

Fig. 6. Mean profiles of alongshore current component (positive = northwestward) at three locations averaged over all stations within $50 \mathrm{~km}$ off the coast. Broken lines represent flow before the final onset of the SW-monsoon, heavy lines flow after the spin-up of the northern Somali gyre. 
Models of the Somali Current flow regime so far focused on the development of the upper layer flow in response to the onset of the SW-monsoon [for discussions, see Leetmaa et al., 1982; Philander and Delecluse, 1983].

It has been established, both from modeling and observations, that the Somali Current dynamics are different north and south of about $4^{\circ} \mathrm{N}$. Interpretations of the near-surface cross-equatorial jet in terms of different models agree quite well with observed response, but modeling of the generation of the northern gyre and collapse of the two-gyre system in the late SW-monsoon is still rudimentary. Some layered models [Cox, 1976; Hurlburt and Thompson, 1976] generate deep, southward flow below the Somali Current; but, as these models do not represent the observed near-surface flow realistically, their flow patterns at depth cannot be expected to be realistic, either.

During the SW-monsoon, winds are southerly and therefore favorable for upwelling to occur along the Somali coast. Undercurrents have been observed as a typical feature of mid-latitude upwelling regions at eastern ocean boundaries, and models of upwelling have been successfully employed to explain coastal undercurrents. In the following paragraphs we will discuss the structure and evolution of the deep southward flow for the various seasons, as given by the development of the wind system.

The NE-monsoon situation (November-February). During November to February our observations near $5^{\circ} \mathrm{N}$ show that the Somali Current reaches to and beyond the deepest measurement levels. The mean southward speed decreases steadily from $40 \mathrm{~cm} / \mathrm{s}$ at the surface to $28 \mathrm{~cm} / \mathrm{s}$ and $20 \mathrm{~cm} / \mathrm{s}$ at the two deeper levels (Figure $4 a$ ). Two interpretations are possible for the generation mechanism. One is that the boundary current is part of the coastal Ekman regime caused by the coast parallel NE-monsoon winds. The other interpre-

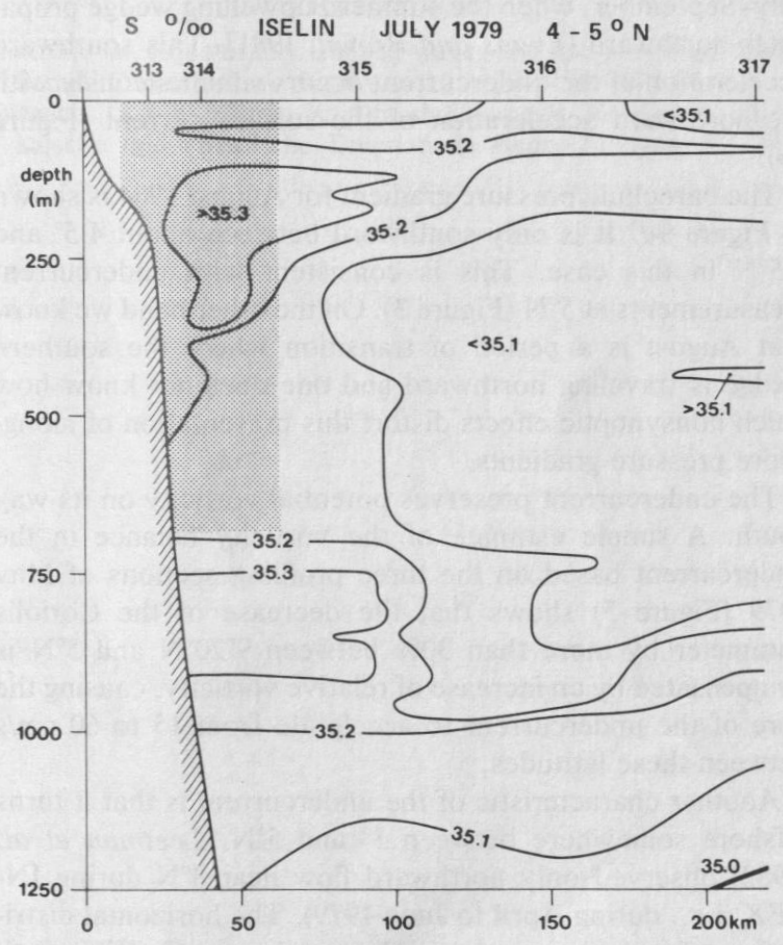

Fig. 7. Distribution of salinity on a section ( 02 in Figure 1) across the undercurrent near $5^{\circ} \mathrm{N}$ during July 1979 . The shaded area corresponds to the current profile given in Figure 6.

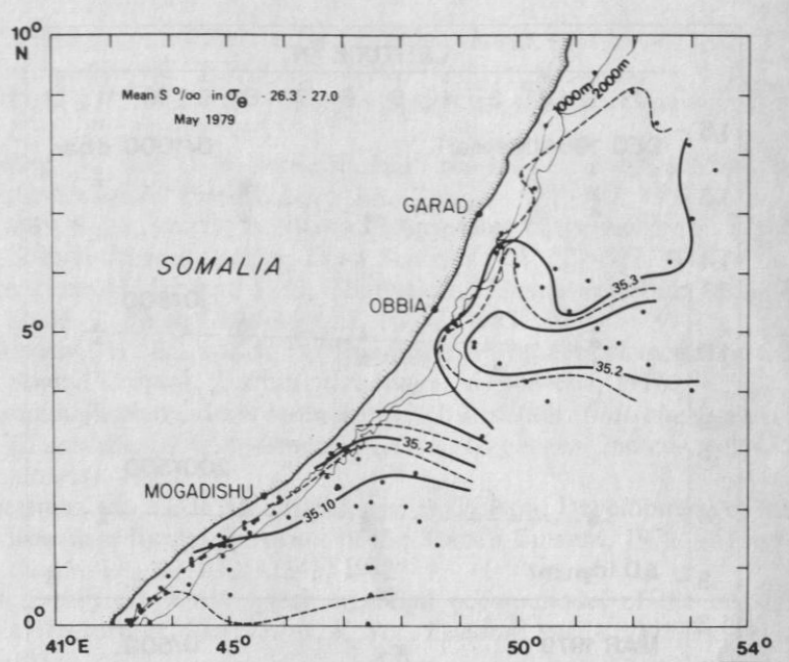

Fig. 8. Mean salinity in isopycnal range $\sigma_{\theta}=26.3-27.0$ during May 1979.

tation is that the southward Somali Current is an inertial boundary current driven by the westward-flowing NE-monsoon Current, which carries about $20 \times 10^{6} \mathrm{~m}^{6} \mathrm{~s}^{-1}$ relative to $1000 \mathrm{dbar}$ as determined from hydrographic sections obtained during the IIOE (K. Wyrtki, personal communication, 1982).

In the first case, one would expect establishment of a poleward alongshore pressure gradient, and, in the second case, the pressure gradient should be southward. Dynamic heights within about $50 \mathrm{~km}$ of the coast from December 1964 (Figure 9a) do not show pressure gradients at shallow levels but show a significant southward pressure gradient against deep reference levels. This suggests the interpretation that the dominant physics of the Somali Current north of the equator during the NE-monsoon is that of a deep-reaching inertial boundary current and that the local Ekman boundary regime processes are not of much importance there. It is not known why the pressure gradient in the range $0 / 1000 \mathrm{dbar}$ (Figure $9 a$ ) just north of the equator reverses to northward again.

The spring transition (March-April). During the cessation of the NE-monsoon, the winds switch to an easterly direction [Schott and Fernandez-Partagas, 1981]. As a result, the Somali Current north of $5^{\circ} \mathrm{N}$ reverses while still flowing southward south of that latitude [Schott and Quadfasel, 1982]. This flow reversal in the northern part is, however, limited to the upper $150 \mathrm{~m}$ of the water column. The strong onshore flow at $5^{\circ} \mathrm{N}$ causes meridional pressure gradients toward the north and south at that latitude (Figure $9 b$ ). Underneath the northward-flowing surface current there still exists a southward flow that is now an undercurrent, although its speed has decreased somewhat (Figure $4 a$ ).

Response to the first onset (May-June). After the first onset of the SW-monsoon which establishes weak southerly winds in early May, favorable conditions for coastal upwelling are established north of $4^{\circ}-5^{\circ} \mathrm{N}$. A narrow northward flowing surface jet is generated along the coast [Swallow et al., 1983] and the sea surface drops by more than 12 dyn $\mathrm{cm}$ between $9^{\circ} 30^{\prime} \mathrm{N}$ and $5^{\circ} \mathrm{N}$ (Figure 9c). This equatorward pressure gradient drives the southward undercurrent, which reaches speeds of up to $60 \mathrm{~cm} / \mathrm{s}$ near $5^{\circ} \mathrm{N}$ (Figure 5). The baroclinic flow structure during this time has been modeled 


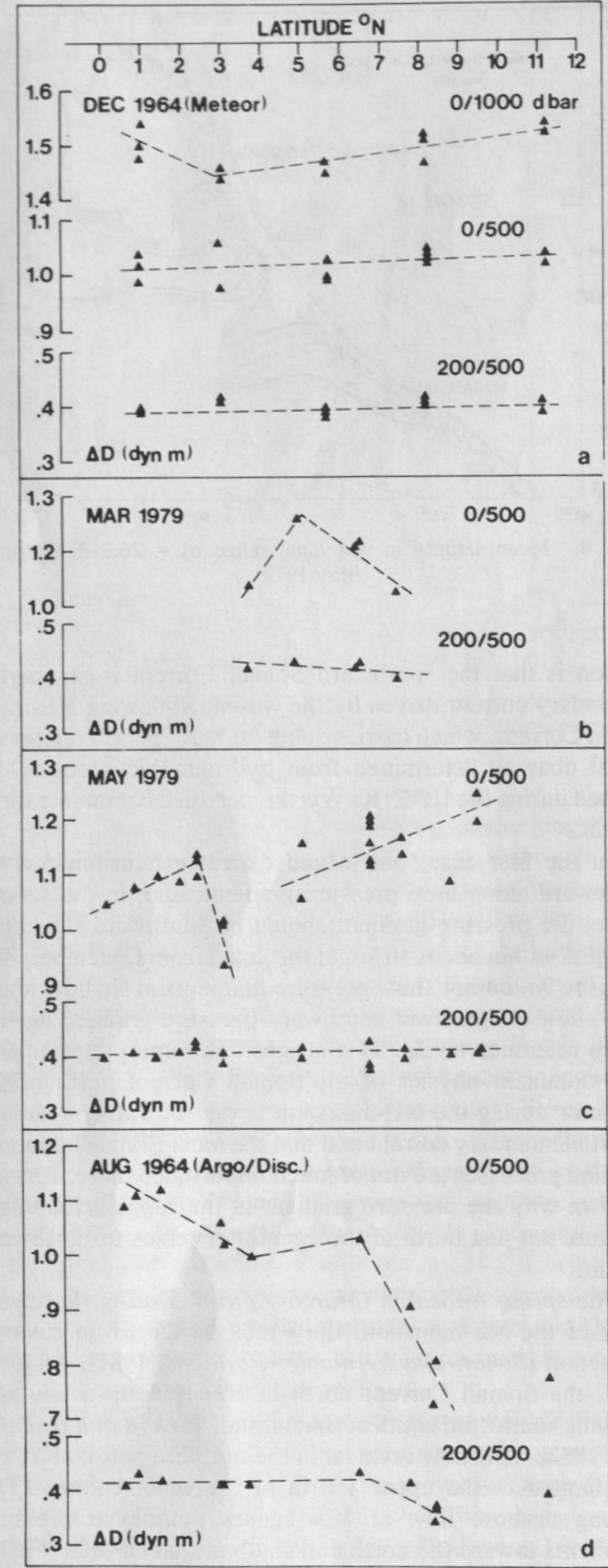

Fig. 9. Dynamic topography along the Somali coast during various seasons. Shown are dynamic heights of sea surface and 200 dbar level relative deeper levels. December 1964 data are from Dietrich et al. [1966]; August 1964 data from Swallow and Bruce [1966].

successfully by various authors [e.g., Hurlburt and Thompson, 1973: McCreary, 1981].

This result, derived from measurements with profiling current meters, appears to be in disagreement with the mean monthly current speeds observed at $5^{\circ} \mathrm{N}$ from the moored instruments (Figure 3): These show a minimum in the undercurrent speed during the early SW-monsoon from May to July, just during the time when the classical upwelling situation exists. An explanation for this discrepancy might be the fact that the $5^{\circ} \mathrm{N}$ mooring was located right in the upwelling wedge separating the southern Somali Current loop from the northern regime during this time period [Evans and Brown, 1981]. The offshore turning of the southern branch is indicated by the northward pressure gradient at $0 / 500 \mathrm{dbar}$ between 2.5 and $3.5^{\circ} \mathrm{N}$ (Figure $9 c$ ). One has also to consider that the moorings at $5^{\circ} \mathrm{N}$ are located some $30 \mathrm{~km}$ offshore (i.e., east of the high speed core of the undercurrent (Figure 5)). Furthermore, the mooring data represent monthly means, while the curent profiles are spot measurements, which are possibly aliased by low-frequency current fluctuations.

Response to final onset (June-July). The second and final onset of the SW-monsoon is characterized by sustained strong winds of over $20 \mathrm{~m} / \mathrm{s}$ speed over the northern Somali Basin. At $5^{\circ} \mathrm{N}$ the monthly means do not show much difference between the first onset and the final onset; the current profile stays about stationary during this time (Figures 3 and $4 b$ ). The individual data from INDEX' 79 seem to suggest that the core of the undercurrent near $5^{\circ} \mathrm{N}$ rises during this time as shown by the current profile measurements (Figure 6). Farther to the north, however, the response to the final onset during INDEX ' 79 is much more drastic. There, the deep-reaching northern Somali gyre spins up after the final monsoon onset, destroying the southward flow at the undercurrent level (Figure 6).

Late summer monsoon (August-September). Since the INDEX ' 79 current measurements in the northern Somali Basin do not extend beyond July, we have no information on the time at which the undercurrent re-establishes itself during 1979. The mooring data at $5^{\circ} \mathrm{N}$ indicate (Figures 2 and $4 a)$ an acceleration of the undercurrent right after the breakdown of the two gyre system, which occurs during late July-September, when the southern upwelling wedge propagates northward [Evans and Brown, 1981]. This southward acceleration of the undercurrent occurs simultaneously with the northward acceleration of the surface current (Figure $4 b)$.

The baroclinic pressure gradient for August 1964 is shown in Figure $9 d$. It is only southward between about $4.5^{\circ}$ and $6.5^{\circ} \mathrm{N}$ in this case. This is consistent with undercurrent measurements at $5^{\circ} \mathrm{N}$ (Figure 3). On the other hand we know that August is a period of transition where the southern wedge is traveling northward and one does not know how much nonsynoptic effects distort this presentation of alongshore pressure gradients.

The undercurrent preserves potential vorticity on its way south. A simple estimate of the vorticity balance in the undercurrent based on the three profiling sections of May 1979 (Figure 5) shows that the decrease of the Coriolis parameter by more than $30 \%$ between $9^{\circ} 20^{\prime} \mathrm{N}$ and $5^{\circ} \mathrm{N}$ is compensated by an increase of relative vorticity, causing the core of the undercurrent to accelerate from 15 to $60 \mathrm{~cm} / \mathrm{s}$ between these latitudes.

Another characteristic of the undercurrent is that it turns offshore somewhere between $3^{\circ}$ and $5^{\circ} \mathrm{N}$. Leetmaa et al. [1982] observed only northward flow near $3^{\circ} \mathrm{N}$ during INDEX (i.e., during April to June 1979). The horizontal distribution of salinity at the undercurrent depth (Figure 8) suggests an offshore turning of the flow near $4^{\circ} \mathrm{N}$.

A possible explanation for the offshore turning of the 
undercurrent is the structure of the topographic bump between $4^{\circ} \mathrm{N}$ and $5^{\circ} \mathrm{N}$ (Figure 1). While north of $4^{\circ} \mathrm{N}$ the depth contours run more or less parallel to the coastline, the continental slope just south of $4^{\circ} \mathrm{N}$ is aligned almost in an east-west direction. A southward barotropic flow over such a topography will experience a sharp deflection to the left, similar to our observations that the undercurrent had disappeared at $3^{\circ} \mathrm{N}$. A numerical study of the Peru upwelling region [Preller and O'Brien, 1980] confirms the importance of bottom topography on the undercurrent dynamics. In their model the width of the continental slope decreases rapidly in the downstream direction, similar to the Somali region, leading to a strong offshore turning of the undercurrent.

On the other hand, the latitude of $4^{\circ} \mathrm{N}$ is the approximate boundary between the equatorial and nonequatorial dynamic regimes as obvious from analytical and numerical modeling studies. Here, strong changes in the flow structure and its reponse to the windforcing occur in the upper layer, and it appears not unreasonable to suggest that this change of dynamic regimes also holds for the intermediate layer.

At present there are no models available that explain reasonably well the various stages of the development of the Somali Current flow regime. Especially poorly described is the subsurface circulation which at most includes a baroclinic response to the onset of the SW-monsoon. Our observations, however, show that the whole annual cycle of the wind forcing as well as offshore dynamics and topographic effects have to be taken into account, if one wants to model the subsurface circulation in the Somali Basin realistically.

Acknowledgments. We thank G. Samuels for his assistance with the data processing. Financial support by the Office of Naval Research, contract N 00014-80-C-0042 and by the National Science Foundation under grant ATM-8201432 is gratefully acknowledged.

\section{REFERENCES}

Cox, M. D., Equatorially trapped waves and the generation of the Somali Current, Deep Sea Res., 23, 1139-1152, 1976.

Dietrich, G., W. Düing, K. Grasshoff, and P. H. Koske, Physikalsche und chemische Daten nach Beobachtungen des For- schungsschiffes Meteor im Indischen Ozean 1964/65, Meteor Forschungsergeb., A2, 1-150, 1976.

Düing, W., Large-scale eddies in the Somali Current, Geophys. Res. Lett., 4, 155-158, 1977.

Düing, W., and D. R. Johnson, High resolution current profiling in the Straits of Florida, Deep Sea Res., 19, 259-274, 1972.

Evans, R. H., and O. B. Brown, Propagation of thermal fronts in the Somali Current system, Deep Sea Res., 28, 521-527, 1981.

Hurlburt, H. E., and J. D. Thompson, Coastal upwelling on a $\beta$ plane, J. Phys. Oceanogr., 3, 16-32, 1973

Hurlburt, H. E., and J. D. Thompson, A numerical model of the Somali Current, J. Phys. Oceanogr., 6, 646-664, 1976.

Koninklijk Nederlands Meteorologisch Instituut, Indische Oceaan, Oceanografische en Meteorologische Gegevens, 2nd ed., vol. 135 (charts), 1952

Leetmaa, A., D. R. Quadfasel, and D. Wilson, Development of the flow field during the onset of the Somali Current, 1979, J. Phys. Oceanogr., 12, 1325-1342, 1982.

McCreary, J. P., A linear stratified ocean model of the coastal undercurrent, Phil. Trans. R. Soc. London, Ser. A., 302, 385-413, 1981.

Philander, S. G. H., and P. Delecluse, Coastal currents in low latitudes, Deep Sea Res., in press, 1983.

Preller, R., and J. J. O'Brien, The influence of bottom topography on upwelling off Peru, J. Phys, Oceanogr., 10, 1377-1398, 1980.

Schott, F., and J. Fernandez-Partagas, The onset of the summermonsoon during the FGGE 1979 experiment off the East African Coast: A comparison of wind data collected by different means, $J$. Geophys. Res., 86, 4173-4180, 1981.

Schott, F., and D. R. Quadfasel, Variability of the Somali Current system during the onset of the southwest monsoon, 1979, J. Phys. Oceanogr., 12, 1343-1357, 1982.

Swallow, J. C., and J. G. Bruce, Current measurements off the Somali coast during the southwest monsoon of 1964, Deep Sea Res., 13, 861-888, 1966.

Swallow, J. C., and M. Fieux, Historical evidence for two gyres in the Somali Current, J. Mar. Res., 40 (suppl.), 747-755, 1982.

Swallow, J. C., R. L. Molinari, J. G. Bruce, O. B. Brown, and R. H. Evans, Development of near surface flow and watermass distribution in the Somali Basin in response to the Southwest monsoon of 1979, J. Phys. Oceanogr., in press, 1983.

Wilson, D., Currents and mass transport off the Somali Coast during the SW-monsoon, 1979, MS Thesis, Univ. of Miami, Florida, 1981.

(Received November 15, 1982;

revised March 9, 1983.

accepted March 14, 1983.) 